\title{
Et Udsnit af Nordslesvigs Kirkeliv.
}

Indre Mission i Aarene 1873-7.6.)

Af Jens Holdt, Brede.

I Sommeren 1872 var daværende Sognepræst i Rinkenæs ved Flensborg Fjord $\mathrm{E}$ m i l W a cker Taler ved den aarlige Missionsfest i Christiansfeld. Wacker stammede fra Sydslesvig. Han var født i Degnehjemmet i Kotzenbüll ved Tønning den 16. 5 . 1839. Dog var han ikke ukendt i de nordlige Egne af Hertugdømmet, idet han fra $1856-60$ havde besøgt den danske Latinskole i Haderslev. I disse Aar var han kommet i Berøring med de religiøst vaagne Kredse i Haderslev og Omegn, der jo i mangt og meget stod under Indflydelse af Herrnhuterne $i$ det nærliggende Christiansfeld, dette Bønnens og Arbejdets velsignede Værksted i vor nordslesvigske Hjemstavn.

Sit teologiske Studium havde den unge Student under lovende Udsigter begyndt ved Københavns Universitet. Men et nationalpolitisk Fejlgreb fra dansk Side havde drevet ham bort fra den danske Hovedstad. De slesvigske Studenter havde nemlig forfattet en Adresse til Kongen, i hvilken de som danske Studenter takkede Gud for, at de ikke var bleven underviste i Løgn og Mened ved Kiels Universitet. Man maa for at forstaa en saadan Henvendelses berettigede Motiver, kunne sætte sig lidt ind $i$ hin Tids nationalpolitiske Spænding. Det forkerte var imidlertid, at man forlangte alle slesvigske Studenters Underskrift. En saadan kunde og vilde Wacker som Søn af tyske Forældre ikke give. Han tabte derfor med eet Slag alle sine Undervisningstimer og Stipendier og foretrak sammen med et Par andre tysk. sindede Studenter at fortrække. En kold Februarnat i Aaret 1861 tog han som Dækspassager med Skib til

1) De til Raadighed staaende Kilder er ikke nær alle udtømte, saa Fremstillingen kun maa betragtes som værende af foreløbig Art. 
Kiel. Hans videre Uddannelse skulde nu, til Trods for, at de okonomiske Vilkaar havde ligget meget gunstigere for ham i København, foregaa i tyske Omgivelser, ved Kiels og Berlins Universiteter.

Efter den politiske Omvæltning i 1864 var Wacker, der tog sin Eksamen i Kiel ved Paasketid 1866, blandt de bedst egnede til at sendes til Nordslesvig. Det nationale Sindelag var det rette. Begge Sprog beherkede han. En bevæget, baade af dansk og tysk Aandsliv befrugtet Uddannelsestid havde han bag sig. Det har derfor sikkert været med Glæde, at det nye tyske Kirkeregimente i Aaret 1867 indsatte ham som Sognepræst for Rinkenæs, efter at han først havde været Hjælpepræst et Aarstid i Ketting paa Als. Forventningerne blev ikke skuffede. Præsten Wacker med sine stærke teologisk-videnskabelige og ikke mindre praktisk-kirkelige Interesser kom til at indtage en forende Stilling i Nordslesvigs Kirkeliv i den kommende Tid. 1870 giftede han sig med Maria Petronelle Plum fra Godset Cathrinedal ved Stege. ${ }^{1}$ )

Vi vil her beskæfige os med et lille Afsnit i vor snævrere Hjemstavns kirkelige Liv, som mere end fra nogen anden fik sit Præg fra Wackers Person og Virke. Wacker var - for at bruge et Feilbergsk Udtryk - i Besiddelse af en stærk "Udstraalingsevne". Der var Aand $i$ den Mand. Og det kendtes paa hans Omgivelser og paa det, han tog fat paa. Det mærkes ogsaa i den mindre Episode i vort Kirkeliv, der her skal forsøges belyst.

Louis Blauenfeldt, den danske Indre Missions Historiker, har i 1919 udgivet et lille Skrift om "Indre Mission i Sønderjylland indtil 1911«, men springer i sin Fremstilling fra »Kirkelig Forening til Guds Riges Fremme i Slesvig “ af 1868 , der sygnede hen under Krigen i 1870-71, over til "Kirkelig Forening for Indre Mision i Nordslesvig « af 1886 , d. v. s. fra GroveRasmussen og Bladet "Elias" til Tonnesen og "Sæde-

1) Ang. Wackers Personlighed og Livsværk henvises til Jubilæumsskriftet "Ev. luth. Diakonissenanstalt Flensburg 1874-1924" ved dens nuværende Forstander Carl Matthiesen, S. $17-34$. 
kornet ".") Midt imellem disse to kirkelige Vækkere stod imidlertid en Tidlang Wacker med "Kirkeligt Søndagsblad «.

Det forekommer mig, at denne Wackerske Periode, som hidtil af ikke uforstaaelige Grunde synes at være ret ukendt og upaaagtet, fortjener at drages frem, fordi den i Virkeligheden maa anses for at være 1) et betydningsfuldt L e d i den historiske Udvikling og 2)-tillige indeholder Begyndelserne til forskellige kirkelige $\mathrm{Nydannelser,} \mathrm{der} \mathrm{senere}$ kom til at betyde saa meget for vore kirkelige Forhold her mellem Kongeaa og Skelbæk, nemlig A s y lsagen, Diakonissesagen og Missions s a gen ude og hjemme. Ved de Strømninger, vi her stilles overfor, ved disses Art og deres indbyrdes Brydning, i Særdeleshed 3) i Synet paa Lægmandsforkyndelsen, er dette Tidsafsnit desuden lærerig for Situationen i Dag og i Fremtiden.

Krigen i 1870 havde, som det er Krigstiders Art, lammet det kirkelige Liv paa mange Maader, men fremfor alt havde den udslukket ethvert Haab om en foreløbig Endring af de statspolitiske Forhold for Nordslesvigs Vedkommende. Tanken om en Opfyldelse af Pragfredens $\$ 5$ maatte efter Napoleons Nederlag skydes ud i en uvis Fremtid. Dermed var ogsaa den kirkelige Vækkergerning, som sidst i Tredserne udøvedes af danske Præster som GroveRasmussen i Gram, senere i Fole, og Johansen i Haderslev, dømt til Ophør, idet disse to Præster, som under Krigen ikke vilde bede for de tyske Vaabens Sejr, maatte forlade Landet, og Bladet "Elias" meget snart derefter maatte gaa ind.")

Men det kirkelige Liv, som var vakt og især blev baaret frem af gode Mænd blandt Lægfolket, der-

1) Det samme gør Tonnesen i en Oversigt "Indre Mission i Nordslesvig $i$ "Kristelig Folkekalender for Nordslesvigu for 1910. Han har kun Bemærkningen "Sagen laa stille i en Rrekke af Aaru.

2) Dette Tredsernes kirkelige Rore er skildret af H. Chr. Beck i et Foredrag "Indre Mission i Sønderjylland i Tredserne«, udgivet paa Tryk i 1908, og derefter suppleret med vigtige Oplysninger af Mads Jensen i "Den Nordslesvigske Kirkesag" 1909, Nr. 2 og 4. Smlgn. L. Blauenfeldts og Tonnesens anf. Skr. 
iblandt Kolportør og Lægprædikant Mads Jensen i Jagerup, forlangte sin Fortsættelse og Vækst. Livets Lov er jo frem for alt Fornyelsens og Vækstens Bevægelse. Som Forholdene imidlertid nu laa, politisk set, delte Strønmen sig i to Arme. Vi stilles her overfor den første Deling inden for et samlet kirkeligt Arbejde i vor nationalt splittede Hjemstavn, som for en væsentlig Del foraarsagedes af nationalpolitiske Grunde. Som bekendt blev det ikke den sidste.

En Del af de Kredse og Hjem i det nævnte kirkelige Røre, der tillige var vakt til national dansk Bevidsthed, fandt deres Hjem og Voksesteder inden for clen nordslesvigske danske Frimenighedsbevægelse, der i Aarene lige efter 1870 satte sine forste kraftige Skud i Haderslev Vesteramt. ${ }^{1}$ )

Medens imidlertid denne nationalt dansk prægede kirkelige Strømning af let forstaaelige Grunde maatte faa sit Leje uden for den statskirkelige Ramme, forsøgte de, der blev i Statskirken under tysk Kirkeregimente, ogsaa at samle sig paany og finde nye Rammer for deres kirkelige Liv og Virkelyst. Vi vil i disse Kredse træffe paa Folk, der i Forvejen var nationalpolitisk orienteret mod Syd, dog især paa saadanne, der helst vilde unddrage sig den politiske Strid og hyldede en vis national Indifferentisme, men til Gengæld brændte i Kærlighed til Hjemstavnen, det lille havombruste Land mellem Kongeaa og Ejder. Endvidere var der naturligvis ikke faa, der var dansksindede, men paa den anden Side $\mathrm{i}$ en vis religiøs Konservatisme ikke kunde finde sig til Rette med den grundtvigske Maade at leve Kristenlivet paa, som den kom frem i Frimenigheden, og heller ikke kunde tænke sig at forlade det fra Fædrene nedarvede Kirkehus. Varmest paa Sinde laa imidlertid for dem alle Guds Riges Fremme.

Opfordringen til ny kirkelig Samling efter |Krigens adsplittende Aar udgik - denne Gang som tidligere - fra Haderslevegnen, hvor man i Sensommeren 1872 paa et Møde af Missionsvenner besluttede at opfordre den til Indledning nævnte Pastor Wacker

1) Smlgn. Thade Petersen: "De sønderjydske Frimenigheders Historie», 1924. 
i Rinkenæs til at udgive og redigere et o p b y g g elig t Ugeblad med akonomisk Støtte fra den bestaaende Missionsforening der paa Egnen. Man havde sikkert i sin Tid været gla:d for Bladet "Elias« og tænkte nu paa en Fortsættelse af hint Blads Gerning under en ny Skikkelse. Wacker tog imod Opfordringen og udsendte fra Nytaar 1873 wKirkeligt Søndagsblad ", hvis Maal det skulde være at "prædike den korsfæstede Kristus« (Bladets Motto siden 1874) og dernæst at "samle Missionsvennerne i vore Egne og være et Foreningspunkt for Missionslivet iblandt os", for derved at "tjene vor ev. luth. Kirke $\mathbf{i}$ dens indre og ydre Mission (.. $)$

Den unge viljestærke og veludrustede Præst, der dengang stod midt $i$ Trediverne, lagde al sin Kraft og Indsigt ind i Opgaven og løste den, efter hvad man kan skønne, med Held. Det meste af Bladets Indhold skrev han selv. Han fremforte et mandigt Trosvidnesbyrd, talte til kristelig Afgørelse og Inderliggørelse og lagde særlig Vægt paa kristelig Undervisning. Vi kan karakterisere hans Budskab som Katekismuskristendom i god Forstand med et vækkende Islæt. Tendensen er afgjort kirkelig, folkekirkelig nøgtern i Modsætning til alt sekterisk Sværmeri om dẹn "rene Menighed ". Pietisme og Metodisme i Renkultur var alle Dage hans Arvefjender. Han vilde være luthersk, og var det i Vidnesbyrdets Frimodighed, medens hans teologiske Formulering vel nok i nogen Maade tor kaldes efter-luthersk. Allerede i Bladets Indledningsord sporer vi Tankerne til hans senere Hovedværk om "Frelsesordenen", en dybt og vidt favnende Kommentar til Luthers Forklaring til 3. Trosartikel.

Bladet, der fremtraadte i tospaltet Kvartformat med fire Sider ugentlig, blev det første Aar trykt i "Frejaus Officin i Aabenraa, derefter i "Dannevirke«s Trykkeri i Haderslev, idet Missionsforeningen for Haderslev og Omegn ved P. Matthiesen stod som Forlægger. Anbefalet af en Kreds af Præster og Lærére vandt det flere og flere Abonnenter. Ved Slutningen

1) "Kirkeligt Søndagsblad" (herefter citeret "K. S.«) 1. Aarg. 1873, Nr. 1 og 12. 
af 1. Kvartal havde det 500. Det rustede sig til at gøre en god kirkelig Gerning i Nordslesvigs Kirkesogne. Efterhaanden dukker i dets Spalter de kirkelige Interesser frem, der paa den Tid rørte sig indenfor Statskirkens Rammer.

Der er først A s y ls a g e n at nævne, der fik sin varme Talsmand i Orgelbygger Jürgen Jacobsen i Haderslev, som allerede i Maj 1873 fremkommer med et Opraab i Bladet, hvilket her skal gengives i Uddrag: "Hvo som annammer et saadant Barn i mit Navn, innammer mig, siger den Herre Jesus (Math. 18, 5). Ihukommende dette Jesu Ord lader os bygge et $\mathrm{Hjem}$ for foraeldreløse Børn. Trang til et Hjem, en christelig Opdragelsesanstalt for forældreløse og forsønte Børn, er vistnok i haj Grad forhaanden, ogsaa her iblandt os i Slesvigs dansktalende Deel. Mig synes det maatte være noget af (let Første og Bedste, den indre Mission hos os skulde tænke paa, at vi snarest muligt fik et Huus bygget i dette Ojemed paa et Sted, som havde en gunstig Beliggenhed for den nordslesvigske Befolkning. Allerede i flere Aar laa denne Tanke mig paa Hjerte og jeg har ogsaa allerede omtalt den for adskillige Venner.... Det er for omtrent tre Aar siden, at denne Plan beskæftigede mig saa levende, at jeg Dag og Nat tænkte derpaa.... For kort Tid siden have vi her i den dansktalende Deel af Slesvig begyndt en Missionsgerning for Hedninger, navnlig ved dette Blads Udgivelse. Vort Onske or ogsaa at virke for den indre Mission, saavidt Herren giver Naade dertil, da ydre og indre Mission ingenlunde kunne skilles ad; thi skal der $i$ den rette Aand virkes for Hedningernes Omvendelse, maa Hjerterne herhjemme først omvendes.... Hvis dette nu finder hjertelig Deeltagelse, bedes de kjære Venner at offre en liden Gave til dette $\emptyset$ jemed, enten paa engang eller aarlig, som Vorherre giver dem Evne og Hjerte til ...... Haderslev, den 1. Maj 1873. J. J. - - Forslagsstilleren meddeler desuden, at han har købt en Gaard i Mjols ved Rødekro, paa hvis Jorder han stiller en større Byggeplads til Raadighed for en Anstaltsbygning med tilhørende Havejord. ${ }^{\mathbf{}}$ )

1) »K. S.« 18. 5. 1873. 
Dette det første Indlæg i den nordslesvigske Asylsag har jeg citeret saa udforligt, for at give et lille Indtryk af den Mand, der stod bag ved Forslaget. Han hørte til de førende blandt Kirkens Lægmænd paa den Tid, var en kristusgreben Mand og en dygtig Borger i Samfundet. Vi lægger Mærke til hans flydende danske Sprogtone og hans Afgrænsning af Virkeomraadet nemlig "Slesvigs dansktalende Deel«. Jacobsen havde været Medlem af Bestyrelsen i den allerede omtalte Forening, der var bleven stiftet paa et Lægmandsmøde i Vojens den 20. 8. 1868. Allerede $\mathbf{i}$ Indbydelsen til dette Møde, som fortrinsvis udgik fra Lægmænd, havde der ved Sliden af "Udsendelse af Colporteurer og Lægprædikanter« været Tale om "Udøvelse af den christelige $K$ Kjrlighedsgjerning omkring i Menighederne, navnlig med Hensyn til forsømte Børn, Syge o. s. V. "1) Foreningens Vedtægter, som var bleven udformede paa det første Bestyrelsesmøde den 4. 9. samme Aar i Skrydstrup Præstegaard hos H. Lawaetz, pegede ligeledes paa Maalet sat understøtte troende Mænd og Kvinder, som i forskellige Egne ville paatage sig forsømte Børns Undervisning, Sygepleje og andre christelige Kjærligheds-Gjerninger. $\aleph^{2}$ ) Ligesom det næunte Maal for Foreningen af 1868 maa antages at være blevet til paa Baggrund af Eftervirkningerne fra Krigsaarene 1864 og 66, et Forehavende, der dog, saa vidt vides, aldrig fik Tid og Lejlighed til i organiseret Form at føres ud i Virkeligheden, er Orgelbygger Jacobsens Opraab øjensynligt begrundet $i$ Iagttagelser og Erfaringer fra Krigsaarene 1870-71. Han nævner jo ogsaa udtrykkeligt Tidspunktet "for tre Aar siden" fra 1873 at regne, da Tanken optog ham saa levende.

Hermed var Begyndelsen gjort til den nordslesvigske Asylsag, der efter Ophavsmandens Dod den 3. 7. 1876, førtes videre af Sønnen, Sognepræst G. Jacobsen, dengang i Randerup, senere flyttet nordpaa, og den 5. 4. 1877 førte til Stiftelsen af "Nordslesvigsk Asylforening for forsømte Børn", hvis første Formand blev Lensgreve Hans Schack Schackenborg, der vare-

1) "Elias«, 3. Aarg., 1869, Nr. 1.

2) »Elias», 1868, Nr. 18. 
tog denne Post til sin Død den 28. 1. 1905. Theodor Kaftan, dengang ung Begynderpræst i Aabenraa, bestred Sekretærposten de første Par Aar og var iøvigt den, der efter en Studierejse sydpaa i samme Øjemed gav Arbe;det dets Form i Begyndelsen, nemlig den saakaldte Plejehjemsordning. Man havde ingen Anstaltsbygning, men søgte at anbringe de betroede Børn i gode, kristelige Plejehjem. ${ }^{1}$ )

En Maanedstid efter Orgelbygger Jacobsens Opraab i Asylsagen, til hvis Gennemforelse der nu indsamledes Pengemidler gennem Bladet, fremfører Wacker selv Diak on is se sagen i Bladets Spalter. Det sker i Juni 1873. Der var paa den Tid Tale om at oprette et Diakonissemoderhus i Flensborg ved Siden af det allerede bestaaende i Altona. Thi, som Husets nuværende Forstander, Pastor Dr. C. Matthiesen, har udtrykt det: "Hertugdømmet Slesvig, i Særdeleshed dets nordlige Del, kunde i Virkeligheden ikke erobres ud fra Altona. ${ }^{2}$ ) Planen blev med højeste kirkelig Anbefaling vedtaget paa et Møde i Neumünster den 2. 7. 1873 og fortes ud i Livet Aaret efter. ${ }^{3}$ ) "Gid vi blot havde Diakonisser i hver Menighed. Trang til deres Gjerning er der visselig allevegne«, skriver Wacker, der fra Begyndelsen blev denne Kristusgernings, den kvindelige Diakonis, utrættelige Ordfører i vore Egne..)

Ligesom Asylsagen havde været nævnt i Vedtægterne for Foreningen af 1868, saaledes ogsaa Diakonissegerningen. Denne havde endda allerede dengang fundet sin begyndende Virkeliggørelse, idet Diakonisseanstalten i Altona, som var bleven aabnet ved Nytaar 1868, havde sogt at knytte Forbindelser ogsaa med Nordslesvig. Den talte blandt sine forste Søstre ogsaa en ung Kvinde fra Ballum i Nordslesvig, og

1) Se iøvrigt om Asylets Historie: "Nordslesvigsk Asyl gennem 50 Aar. Et Jubilæumsskrift ved C. M. Jensen, Erlev, Haderslev, 1927, og H. Prahl: "Nordschleswigscher Asylverein" i Fr. Gleiss: "Handbuch der Inneren Mission in Schleswig-Holstein, Bordesholm, 1917. S. 280-84.

2) wHandbuch der I.-M. in Schl.-Holst.", S. 171.

3) Smlgn. det anførte Jubilaunsskrift.

4) »K. S.« 15. 6. 73. 
var bleven varmt anbefalet af Pastor Michaelsen i Bjolderup i Bladet "Elias" for 15. 12. 1868, idet samtidig optoges et Opraab fra Husets Forstander, Pastor Biernatzki. Den stærke Medhu for Diakonissegerningen, som paa dette Tidspunkt fra forskellig Side kom til Udtryk i Hertugdømmerne, beroede aabenbart for en stor Del paa den Taknemlighed og Interesse, de ca. 20 Diakonisser fra Fliedners Antalt i Kaiserswerth havde vakt ved deres enestaaende Opofrelse for de saarede og døende i Krigen i 1864.

Den nye Diakonisseanstalt i Flensborg fik paa Grund af mindre heldige Valg til de ledende Stillinger nogle ret vanskelige Begynderaar. Men da saa Wacker selv blev kaldet til dens Forstander i Aaret 1876, var Gerningen blevet lagt $i$ de rette Hænder. Her paa Sproggrænsen mellem Dansk og Tysk kom han til at øve sin Manddomsgerning, der efterhaanden mere og mere ogsaa drog Nordslesvig med ind i sin rigt velsignede Virkekreds. Anstaltens Fremtid syntes dengang at skulle bero paa, om der vilde findes tilstrækkeligt mange unge $\mathrm{Kvinder,} \mathrm{der} \mathrm{vilde} \mathrm{gaa}$ ind $i$ en Diakonisses uselviske Gerning. Wacker var utrættelig $i$ at kalde paa disse og at skildre Diakonissekaldets indre Herlighed for dem, idet han straks fra Begyndelsen lagde Vægt paa Menighedstjenesten. Man tænkte ikke blot paa at uddanne de unge Kvinder til Sygepleje og Sjælesorg paa Moderhusets Hospital og andre Sygehuse i Oplandet, men havde fra forste Færd Tanken henvendt paa Diakonissens Gerning efter det bibelske Forbillede ude i Sognene. $\left.{ }^{1}\right)$ "Menighedsplejen er Diakoniens Krone", har man sagt med Rette. "Barmhjertighed mod Sjælen er Sjælen i al Barmhjertighed " udtrykker det samme.

I Særdeleshed var det Wacker om at gøre, at det dansktalende Nordslesvig ikke skulde komme til at staa uden for det nye kirkelige Arbejdsfelt. Ogsaa fra Nordslesvig søges unge Kvinder til Uddannelse, for siden at give en Del af dem tilbage som Menighedssøstre. Der tilsikres, at begge Sprog skal blive talt i Moderhuset, selv om Hussproget ellers var Tysk. Nordslesvig var da ogsaa repræsenteret allerede i den

1) $"$ K. S.« 6. $7.73 \circ \mathrm{og} 3,5.74$. 
første lille Søsterflok, ja maatte endda give de første "Losepenge", idet Prøvesøster Johanne Nissen fra Dimen ved Aabenraa døde allerede i November 1874 under en Tyfusepidemi. I Begyndelsen af 1875 tor Wacker fastslaa i Bladet, at "Diakonissesagen har begyndt at slaa Rod ogsaa hos os", ihvorvel der endnu var saare langt til det attraaede Maal, nemlig at faa en Diakonisse i hvert Sogn i Nordslesvig. ${ }^{1}$ )

Vi vender, efter at have fulgt de to omtalte nye kirkelige Arbejdsgrene lidt frem paa deres Vej, tilbage til Begynderaaret 1873 igen for at se, hvad der ved Siden af Asyl- og Diakonissesagen mere spirede frem paa den nye kirkelige Arbejdsmark.

I Sommerens Løb afholdtes der flere Steder Missionsfester, ved hvilke Hedningemis ionen kom frem i første Række. Nævnes kan bl. a. Dybbøl, hvor Emil Claussen, en fjern Slægtning til Wacker, er Præst siden 1865, og Sottrup, hvor Lawaetz var flyttet til fra Skrydstrup i Aaret 1871. Disse to Præster havde til Forskel fra Wacker aktivt deltaget i Tredsernes kirkelige Missionsarbejde. Med en vis Ret kan Claussen endda siden hen rose sig af, at det forste Hedningemissionsmøde efter den politiske Omvæltning i 1864 blev holdt i hans Sogn, nemlig den 24. 8. 1868 i Dybbøl Kirke. Ligeledes skal han have været den første Præst i Nordslesvig, der indførte Helligtrekongersgudstjenester. ${ }^{2}$ )

1) $n$ K. S.《 3. 5.74.

2) Ved den nievnte Missionsfest, som er refereret $i$ "Elias" for 15. 9. 1868, talte Michaelsen og Grove-Rasmussen Indre-Missions - eller for at bruge et dengang præget Udtryk "den allerinderste Missions" - Sag. Teksterne var betegnende nok de klassisk indre-missionske om den nye Skabning i Kristus (2. Kor. 5) og om det Guds Lam, der bærer Verdens Synd (Joh. 1). Claussen selv og Müller (dengang i Sønderborg, senere i Adsbøl og Nybøl) til Gengæld vendte Blikket udad til Hedningeverdenen udfra de lige saa klassiske Ydremissionstekster om Høsten, der er stor (Mt. 9) og om Folket, der vandrer i Mørket (Jes. 9). Baggrunden for Hedningemissionens Fremkomst ved denne Lejlighed maa vistnok foruden i Christiansfelds stadigt lysende Forbillede fortrinsvis søges i personlige Indtryk fra Missionsværket i Hermannsburg.

1)e nævite to Præster, Claussen og Lawaetz, maa 
Missionsinteressen herhjemme paa den Tid, først i 70erne, samlede sig foruden om Brødremenigheden i Christiansfeld, som i saa Henseende har været den stadige Paaminder og Indbyder, den vaagne Samvittighed midt i Folkets travle, selvoptagne Hverdagsliv, ogsaa om andre Missionscentraler, saaledes Gossners Mission i Berlin og Hermannsburg i Lüneburger Landet. ${ }^{\text {) }}$

Paa Hermannsburgs Missionsskole fik paa det nævnte Tidspunkt en ung Mand fra Nordslesvig sin Uddannelse til Missionærgerningen. Det var $\mathbf{P}$ o u l Ot t o Petersen. Han kalder Wacker sin Skriftefader og er i sin Tid, da han gik med Tanker om at

siges at være to adle Repræsentanter for en vis formidlende Overgangstype, som der tiere har varet god Brug for i vor Hjemstavns nationalpolitisk omskiftende Historie. H. P. Hanssen, der er barnefødt i Sottrup Sogn, har fortalt mig, at disse to Praster til at begynde med var stærkt knyttede til Indtryk fra dansk Aandsliv. De bragte saaledes især paa Salmesangens Omraade en ny Luftning med sig, idet Tillægget til Roskilde Konvents Salmebog indførtes og blev meget flittigt benyttet ved de friere kirkelige Møder. Senere har det af Claussen udgivne lille Sanghefte "Missionsharpen" til Brug ved Missionsfesterne virket i samme Retning. Lawaetz har ogsaa til sin Død i 1902 baaret dansk Præstekrave. Dog efterhaanden, som Kilderne nordfra mere og mere tilstoppedes, modtog de stærkere Paavirkninger sydfra.

Det or ikke just en misundelsesværdig Lod, der falder i saadanne Overgangspræsters Hænder, til en vis Grai hjemløse og som oftest ikke fuldt anerkendte som de er. De har imidlertid deres gode Plads i Udviklingen som Formidlere af den historiske Kontinuitet og fortjener ikke at glemmes $\mathrm{i}$ en historisk Oversigt over denne.

1) Allerede i 1843 (14. 8.) var der paa Foranledning af missionsinteresserede Lægmænd paa Løgumklosteregnen og i Forbindelse med Christiansfeld bleven stiftet en "Nordslesvigsk Missionsforening", hvis Opgave blev at understøtte Negermissionen paa de kongelig danske Øer i Vestindien. Foreningen udgav fra Nytaar $1844^{\circ}$ et Missionsblad "Evangelisk Missions-Tidende", hvis første Redaktør var den kendte danske Eftermiddagsprædikant i Christiansfeld Niels Johansen Holm. Bladet udgaar den Dag i Dag fra Christiansfeld. I 1911 blev dets Navn forandret til "Brødremenighedens Missionsblad". Smlgn. "Et Jubilæumsskrift. 1893. Den nordslesvigske Missionsforenings Oprindelse i Aaret 1843 for 50 Aar siden« og J. Brodersen: "Fra gamle Dage«, S. 548. 
blive Missionær, af denne bleven henvist til det strengt lutherske Hermammsburg, som Wacker temmelig sikkert har kendt af Selvsyn. $\left.{ }^{1}\right)$ Missionsselskabet foreslog nu at sende P. O. Petersen til Østindien som Nordslesvigs særlige Repræsentant. Hans Underhold skulde Missionsvennerne i Nordslesvig saa skaffe til Veje, medens han selv til Gengæld skulde sende Breve og Efterretninger fra Missionsmarken til Søndagsbladet og derigennem vække og styrke Missionskærligheden herhjemme. Han skulde bære Hædersnævnet "vor Missionær«.

I al Korthed skal gives nogle af hans Data. Han var Landmandssøn og født i Højer den 24. 1. 1844, men havde tilbragt sin Barndom i Nørrejylland. Omkring Konfirmationsalderen blev han som saa mange andre unge fra nordslesvigske Hjem - og forresten fra hele Skandinavien med - sendt til Christiansfeld, hvor han efter et Par Aars Skoletid blev konfirmeret. Siden hen fik han Plads paa en større Gaard ved Kalundborg, som ejedes af en Broder til Pastor Lawaetz, den fra Dansk Indre Mission kendte Proprietær 0. Lawaetz. Sammen med denne sin Husbond havde han været paa en Rejse til Hermannsburg, hvor han saa senere efter nogle Pladser paa større Gaarde i det holstenske var kommen paa Missionsskole. ${ }^{2}$ )

Efter sin Ordination i Hannover den 12. 5. 1875 holdt Missionær Poul Otto Petersen i samme Aars Forsommermaaneder Missionsforedrag omkring i Nordslesvigs Sogne. Hen paa Sommeren rejste han til Madras i Sydindien, for at bringe Evangeliet til Telugufolket. Hans Gerning derude kom til at sætte sin Frugt i Oprettelsen af Missionsstationen Tirupati, som indtil Verdenskrigen blev baaret af Missionskredse her i Nordslesvig. P. O. Petersen fik en haard og streng Arbejdsdag og døde den 4. 2. 1888 af Kolera. Han blev begravet paa Tirupati Kirkegaard, hvor han i Forvejen havde stedt sin Hustru, en Datter af Forstander Hansen, "Lienerhaus« ved Celle, og 5 Børn

1) Smlgn. Henvisningen til Anstaltens Forstander Harms i den paa Tryk udkomne Prædiken af Wacker paa Missionsfesten i Christiansfeld den 10.6. 1872.

2) Smlgn. Selvbiografien i »K. S.« 1875. 
til den sidste Hvile. Tirupatimissionens omskiftelige Historie skal imidlertid ikke skildres her. Vi interesserer os i denne Sammenhæing kun for dens Udspring herhjemme indenfor den her omtalte Wackerperiode i Nordslesvig.

Den faste Opgave paa Missionsmarken, der var overtaget med Missionær Poul Otto Petersens Udsendelse, krævede imidlertid en Organisation som Rygstød herhjemme. Wacker indrykkede da i Søndagsbladet for 13. 6. 1875 følgende Indbydelse: "I Anledning af et i Gravensteen den 3. i denne Maaned afholdt Møde af flere ligesindede Præster og i alle Deltageres Navn indbydes herved Præster og Lægfolk, der i samme Aand og fælles Tro ville arbejde med os, til et Møde i Rødekro den 17. 6. Midd. Kl. 12 for at drøfte Grundlæggelsen af en luthersk Forening til det (hhristelige og kirkelige Livs Vækkelse og Fremmelse (sic!) i Nordslesvig, i Særdeles-. hed med Hensyn til Hedningemissionen."

Denne Indbydelse, der altsaa udgik udelukkende fra Præster og det saadanne, som satte en Streg under deres "lutherske« Indstilling, finder god Modtagelse og samler henved 60 Præster og Læg:olk i Rødekro. Efter Indgangsbøn af Pastor Wacker, der jo maa siges at være den drivende Kraft i Foretagendet, og under Forsæde af Inspektør Ohrt fra Sandbjerg gaar man i Lag med Drøftelsen af den paatænkte Foreningsdannelse.

Man enes om Formaalet og opstiller den nye Forenings Vedtægter, der fortæller os følgende: 1. Man vil gøre et vækkende kirkeligt Arbejde i Nordslesvig, men paa streng ev.-luth. Grund. (Vedtægterne har føjet "ev.« foran Indbydelsens "luth«.) I de paagældende Præsters Opfattelse vil det sige: Indenfor Statskirken og i Tilknytning til og Underordning under dens Embede. Offentlig Forkyndelse bliver alene de retmæssig kaldede Præsters Sag. ${ }^{1}$ ) 2. For-

1) Pastor Dr. Bracker, tidligere Missionsinspektør i Breklum, nu Sognepræst i Medelby, har venligst gjort mig opmærksom paa, at Foreningens Dannelse efter Wackers. egen Antydning skulde være sket $i$ en vis Modsætning til Pastor Jensens Missionsvirksomhed udfra Breklum. Man frygtede for, at den saakaldte "Breklumer 
eningen vil omspænde hele Landet og stiler hen imod at faa Indpas i hvert Sogn i Nordslesvig. "Maatte vor Forening blive et Samlingssted for alle Troende i hele Nordslesvig." Det er de ledendes Ønske. Og Fonspringets Fordel havde man jo paa sin Side. 3. Foreningens Sprog kan kun være det danske, eftersom man lever og virker $\mathrm{i}$ en dansktalende Befolkning. Iøvrigt maa sikkert siges, at man bevidst tilstræbte at være upolitisk i sin Virken. Det gjaldt Guds Riges Fremme. Sigtet skulde være rent kirkeligt, uden at vi dermed vil overse, ej heller bebrejde nogen, at de førende Præster - maaske med en enkelt Undtagelse - var bevidst tysksindede Mænd.

Vi kan som Helled ikke undgaa at faa Indtryk af, at det var Præsterne, der havde Førerskabet ved den her omtalte Foreningsdannelse. Det var dem, der indbød, dem, der førte Ordet, dem, der bestemte Kursen. Foreningen blev da ogsaa overvejende - og det er tillige dens Skæbne - en Præsteforening.

Den foreløbige Bestyrelse, der vælges ved Akklamation, kommer til at bestaa af Præsterne Wacker, Rinkenæs, Claussen, Dybbøl, Nielsen, Højrup, Wolf, Bylderup, og Lægmændene Gaardejer Johannes Kloppenborg, Harreby, Forpagter Gottfredsen, Mjøls, Orgelbygger Marcussen, Aabenraa, Gaardejer Philipsen, Skjelde, og Degn Petersen, Abild.

Af disse har Philipsen, der nu er bosat i Nybal, ikke selv været tilstede paa Mødet, hvilket ogsaa godt kan tænkes om enkelte andre af den her valgte Bestyrelse. Philipsen har imidlertid ikke troet at kunne modtage Valget, hvilket senere meddeles i Bladet. Grundene hertil angives ikke. Men efter Philipsens eget Udsagn overfor mig var det nationale

Geist « skulde faa Indpas i Nordslesvig, idet man misbilligede denne som værende sekterisk. Herimod satte man saa sit højkirkelige Program. Jeg tror ikke, der kan blive Tale om, at Foreningen kun or dannet som Protest mod Breklum. Den er, som paavist, vokset ganske naturligt frem af de hjemlige Krav. Derimod er det meget sandsynligt, at Valget af Forbindelsen med det strengt lutherske Hermannsburg og ligeledes den knæsatte højkirkelige Kurs er sket $i$ en vis Modsætning til det mere lavkirkeligt orienterede Breklum, hvis Missionsanstalt forovrigt først blev grundlagt Aaret efter, nemlig i 1876. 
Hensyn. Han kunde ikke tænke sig at arbejde sammen med »tyske« Præster.

I Anledning af Vedtægternes Offentliggørelse fremkommer der den 11. 7. 75 et kritisk Indlæg $i$ Bladet fra Th. K., der temmelig sikkert er den unge Pastor $\mathrm{T}$ h e o d or K a f $\mathrm{t}$ an, der siden 1873 var Andenpræst i Aabenraa. Jeg anfører dette, fordi det aabenbart er een af de første Lejligheder, ved hvilke den Kaftanske Røst, der senere skulde faa saa afgørende Indflydelse paa Ordningen af Nordslesvigs kirkelige Forhold, begynder at gøre sig gældende. Det var Kritikeren, der mødte frem. Kaftan advarer imod for megen Organisation. Han anser Tegningen af Medlemmer og faste Medlemsbidrag for overflødig og anbefaler iøvrigt en "mere kirkelig-folkelig Karakter" af Foreningen. Altsaa ingen "Stat i. Staten«, men en fuldstændig Indordning under de bestaaende folkekirkelige Forhold. Fyld de bestaaende Institutioner, inden I danner nye, som en norsk Kirkemand engang har udtrykt det. Tanken er vel værd at overveje, men det har hidtil vist sig, at den ret sjældent bliver praktiseret, idet et nyt frembrydende Aandsliv som Regel altid gaar uden om den bestaaende Organisation og skaber sig selv et nyt Legeme. Den unge vil sjældent finde sig i at gaa i den gamles aflagte Klæder. Den nye Vin vil fyldes paa nye Læderflasker.

Foreninger plejer at have et Aarsmøde, hvor Medlemmerne samles og Aarsregnskabet i mere end een Forstand gøres op. Hvad er der naaet i det forløbne Aar, og hvad skal der gribes an i det nye? Den nydannede ev.-luth. Missionsforenings f ø rs t e A arsm ø d e afholdes i Løgumkloster i Dagene 14.-15. 9. 1875. Vi lægger Mærke til, at Mødestedet er lagt mod Vest. Maaske er det foranlediget ved en vaagnende Interesse paa Vesteregnen, der forresten altid har haift Ord for at være kirkeligt mere fremmelig end Østkysten. Her var gamle Traditioner at knytte til og nyt Land at vinde. Vi noterer endvidere som bemærkelsesværdigt, at Aabningsgudstjenesten var overdraget til Pastor Kaftan, der prædikede over 
Teksten: "Ild er jeg kommen at kaste paa Jorden, og hvor vilde jeg, at den var optændt allerede.')

Generalforsamlingen aabnedes af Pastor Claussen, der til at begynde med antydede Nodvendigheden af at slutte sig sammen og virke med forenede Kræfter ogsaa i Guds Rige. Man haabede at samle alle Troende Nordslesvig over i Foreningen. Han selv foretrak en langsom Udvikling hen mod dette Maal, som den sundeste. Som Retningslinjer optrak han følgende: 1) "Vor Forening kaldes ev.-luth.". Den staar paa Kirkens "fulde Bekendelse, som viser sig levende og virksom i Kirkens indre og ydre Forhold, i Kirkeanordninger og Kirkeregiment. Derfor er vi ogsaa kun en Forening indenfor vor Kirkes Organisation .... ikke en Slags Frimenighed.« Denne sidste Bemærkning er aabenbart sagt med Henblik paa den Aaret forud, i 1874, ny oprettede danske Frimenighed i den nordlige Del af Landet. 2) Dernæst: "Vor Forening er en Missionsforening «, d. v. først og fremmest sige Hedningemissionen. "Vi samler os nu forst om vor Missionær Petersen.... Som Medlemnier af Foreningen maa vi derfor paa alle Maader søge at vække og fremme Missionsinteressen herhjemme." 3) Videre: Men Ydre Mission forudsætter Indre Mission, d. e. "Vækkelse og Fremme af det christelige Liv herhjemme. Vi maa paa dette Omraade vel sondre imellem, hvad der tilhører Kirkens Embede som saadant, og hvad der kan være Gjenstand for vor Forenings Opgave. Aldrig ville vi i denne vor Forenings Virksomhed gjøre Overgreb med Hensyn til det, der tilhører det kirkelige Embede. Naar vi kunne gaa Haand i Haand med det allevegne, faa vi en større Velsignelse. En Hjælp, en Haandsrækning for det kirkelige Embede skal vor Forening være. Til den indre Missions Opgaver hører for Øjeblikket a. Bogdepot og Colporteurer, b. Diakonissesagen .... Colporteurerne skulle gaa rundt i Husene, sælge gode Bøger og tale et godt Ord der.... Diakonisseinteressen bør samle sig om Flensborg. "“)

1) Optrykt i »K. S.《 5. 12. \%5.

2) "K. S.« 24. 10. 1875 . 
Indledningsforedraget efterfulgtes, som Referatet melder det, af en "levende Debatte«. Iblandt dens Vedtagelser vil særlig følgende Beslutning interessere os: "Der udsendes Colporteurer. Om Lægprædikanters Virksomhed udsættes Beslutningen indtil næste Generalforsamling." Bag denne sidste Tilføjelse maa vi sikkert fortrinsvis søge Anledningen til Generalforsamlingens Livlighed. Her var et Punkt, hvor det brændte paa allerede i denne den forste Sammenkomst efter Foreningens Stiftelse. Kaftan havde i sin Prædiken allerede rørt ved Spørgsmaalet, sikkert vidende, hvad der laa i Luften.

Der er ingen Tvivl om, at Kravet om Lægmandsforkyndelse, som havde haft Hjemstavnsret i Tredsernes Indre Missionsbevægelse og paa det nærværende Tidspunkt blev udøvet netop her paa Vesteregnen af Lægprædikanten Hans Pedersen Nielsen i Skads, er bleven fort frem fra Lægmandsside, og sikkert med en vis Styrke. Maaske er det Degn Holm fra Ballum, som senere skulde træde offentlig frem i dette Anliggende, der allerede denne Gang har rort ved Spørgsmaalet. Maaske har ogsaa H.P. Nielsen selv været til Stede paa Mødet. Han skal engang i sine Begynderaar have tilbudt sig som Lægprædikant til en Præsteforening, men være bleven afvist. Pastor Lawaetz skal dog have opmuntret ham til ikke at nedlægge Staven, men at rejse paa egen Haand, medens Pastor Wacker skal have sagt til ham: "De maa nok rejse, Hans Pedersen, men De maa ikke prædike. "1)

Vi kan i Forbigaaende ogsaa minde om, at det var Aaret forud, at Lægmanden, Lærer Cornelius Appel var bleven ordineret til Præst i Rødding Frimenighed. Men Debatten paa Generalforsamlingen i Logumkloster endte altsaa denne Gang med, at Præsterne med deres højkirkelige Anskuelser vandt Tid ved et Aars Udsættelse af Afgørelsen, om Foreningen som saadan skulde antage og udsende Lægprædikanter eller ej. Man nøjedes foreløbig med Bogsælgere.

1) Smlgn. Luth. Missionsforenings Mindeskrift, S. 165 -166 , der dog sammenblander de to Foreninger af 1868 og af 1875 . 
Af den paa Stiftelsesdagen i Rodekro valgte $\mathrm{Be}$ styrelse udgik Philipsen, Skjelde, der dog ikke havde taget imod Valget, og Pastor Wolf, Bylderup, og indtraadte i Stedet Degn Holm, Ballum, og Pastor Lawaetz, Sottrup. Alt i alt var det en Forøgelse af det lægmandsvenlige Element i Bestyrelsen. Til dette maa blandt dens Præster henregnes Nielsen og Lawaetz, der maaske allerede ved dennne Lejlighed har støttet eller endda frembragt Lægmandskravet. 10 Aar senere var det de to, der gik med Tonnesen.

Den følgende Dag holdtes den egentlige Missionsfest med Taler af Præsterne Claussen, Wacker, Wolf (siden 69 i By.lderup, fra 65 i Skads), Nielsen (siden 73 i Højrup), Prahl (siden 73 i Mjolden) og Lawaetz. Der var samlet ca. 2000 Mennesker og indkom et Missionsoffer paa 924,70 M. til "vor Missionær«. Festen var i det hele vellykket og syntes at forjætte en god Fremtid for Foreningen. "Vi vilde ophøje Korset iblandt os og kunde sige ved Festens Ende, at naar vi opløftede vore Øjne, saa saa vi Ingen uden Jesum alene«, slutter Referatet.

En Opfordring fra Bestyrelsen i Bladet for 21. 11. 75 tilsigter at føre de paa Generalforsamlingen vedtagne Beslutninger ud i Livet. Der meddeles, at "Nordslesvigs evang.-lutherske Missionsforening definitivt har constitueret sig. Henved 50 Personer, deriblandt 16 Præster, ere ved Navnsunderskrift tiltraadte Foreningen". Flere aktive Medlemmer bedes melde sig, ligesom der udbedes Pengebidrag til Bogdepotet. Endelig opfordres "Personer, som maatte være skikkede til at gaa ud som Foreningens Colporteurer og som af Herren have modtaget Tro og Frimodighed til denne Gjerning, snarest muligt at melde sig." Og der tilføjes for en Sikkerheds Skyld: "Colporteurerne skulle ikke holde Forsamlinger, men kun sælge Bøger og derved, naar Herren giver Lejlighed, tale et godt Ord i Husene, til hvilke de komme ..." De skulde gerne begynde efter Nytaar 1876 og faar en fast Dagløn fra Foreningens Kasse. I Sommermaanederne skal Bogsalget dog hvile, saa de i den Tid maa søge anden Bestilling.

Paafaldende er det lille Tal 50 af de skriftligt anmeldte Foreningsmedlemmer, medens dog Præ- 
sternes Antal (16) i Forhold her til maa siges at være ret stort. $\left.{ }^{1}\right)$ Det var jo ogsaa Præsternes Anskuelser, der sejrede i Løgumkloster, medens vi tør antage, at en Del af de førende iblandt Lægfolket er draget utilfredsstillet hjem fra Foreningens forste Aarsmade.

Fra Aaret 1875 fortjener endnu at anføres, at vi ved en Missionsfest i Brøns den 17. 11. for første Gang træffer Breklum som Parthaver i Kollekten. Fordelingen af denne er interessant derved, at den vistnok giver et nogenlunde træffende Billede af, hvordan Landet laa paa det Tidspunkt med Hensyn til Hedningemissionsinteressen herhjemme. Pengene fordeltes saalunde: ${ }^{1 / 3}$ til Brødremenigheden, ${ }^{1 / 3}$ til Kols Missionen (Gossner), $1 / 6$ til Breklum og $1 / 6$ til de slesvigske og holstenske Missionærer, som gaar under Navnet "unsere Missionaire", deriblandt "vor Missionær . $^{2}$ )

Med Aaret 1876 begynder vi paa tredje og sidste Akt i det her fremdragne kirkelige Intermezzo i Nordslesvig. Vi har hørt om den forjættende Begyndelse, idet man tog Arven op efter den ved de ydre, politiske Forhold opleste Forening af 1868 . Vi har fulgt den voksende Fremgang, som kom Asyl-, Diakonisse- og Hedningemissionssagen til Gode. Vi skal nu stilles overfor den bratte Afslutning, der hidførtes $i$ Anledning af $\mathrm{L} æ \mathrm{gmandsspørgsmaalet.}$ Den indledes med, at Wacker i Januar 1876 meddeler, at han til Foraaret vil flytte til Flensborg som Præst og Forstander for Diakonisseanstalten dér. Han haaber dog at kunne bevare Redaktørhvervet, som er vokset ham til Hjertet, og dermed at holde Forbindelsen vedlige med Nordslesvigs Befolkning, som ligeledes staar hans Hjerte nær. Han agter for Fremtiden at lade et lille Maanedsblad "Blade fra den ev.-luth. Diakonisseanstalt i Flensborg«, følge med Søndagsbladet, for at give Oplysninger om Gerningen paa Flensborgs Moderhus og for at kalde paa den bærende Kærlighed fra Menighederne.

1) Til Sammenligning kan næunes, at den i 1843 stiftede "Nordslesvigske Missionsforening " havde 162 indskrevne Medlemmer ved sin Start.

2) »K. S.《 5. 12. 75 . 
I Februar kan der meddeles, at den første Kolportør - det blev den eneste - nu er antagiet og udsendt, nemlig Adolph Jensen, af Profession Skomager i Løgumkloster. Han berejste Vesteregnen med sin Bogtaske. Hans Virketid varede dog kun nogle Aar. Senere er han udvandret til Norge og død deroppe hos en Søn.

Under Wackers Omflytning til Flensborg overtager Claussen indtil videre Redaktionen af Søndagsbladet. Wacker ønskede senere igen at overtage dette Hverv, men Omstændigheder"ne førte det med sig, som vi siden skal se, at hans Tid paa denne Post nu var til Ende.

I Sommerens Løb holdes der Missionsfester rundt omkring i Sognene, saaledes i Dybbøl, Sottrup, Vonsbæk, Højst, Møgeltønder, Brede o. a., deriblandt ogsaa en Del nye Steder. Det er vel særlig de 16 Præster, der med Navnsunderskrift var tiltraadt Foreningen, som indenfor deres Sogne virker for Sagen.

Hovedinteressen kommer dog til at samle sig om d e t andet A a r s m ø de, der er berammet til Rise Sogn den 6. og 7.9.1876 og sikkert har været imødeset med en vis Spænding. Bølgerne skulde paa selve Dagen komme til at gaa højt og til sent at lægge sig. ${ }^{1}$ )

Wacker havde selv overtaget Indledningsgudstjenesten i Kirken. Han talte om Kaldet til Missionsarbejdet. Alle er bleven kaldede i Daaben. Nogle modtager et Kald gennem særegne Naadegaver. Andre faar "det ydre Kald ifølge et bestemt Ord efter Guds Orden«, hvorved han aabenbart tænker paa Kaldet til Præstegerningen, til Prædikeembedet.

Efter Gudstjenesten begav man sig til Salen i Rødiekro, hvor Generalforsamlingen skulde finde Sted. Det daarlige Vejr havde holdt en Del Medlemmer og Venner hjemme, navnlig fra Vesteregnen. Maaske var ogsaa Interessen bleven mindre efter sidste Aarsmøde i Løgumkloster. Den stedlige Egns Befolkning var maaske heller ikke saa stærkt missionsinteresseret som vesterude. Wacker aabnede

1, Smlgn. »K. S.《 29. 10. og 5 11. 76. 
Mødet og begyndte med at foreslaa Pastor Claussen til Formand i sit eget Sted. Formandsskiftet begrundede han med, at han ifølge sin Ansættelse i Flensborg ikke mere kunde yde det, der krævedes af en Formand. Derefter gaves Ordet til D e g n $\mathrm{H}$ olm fra Ballum, der skulde "referere over det opgivne Emne om Lægmands Virksomined for Guds Riges Fremme og navnlig om Lægmands Prædiken, om Forkyndelsen af Guds Ord ved Lægmand."

Det hedder i Referatet, som vi vil holde os til: "Med megen Varme, med stor Besindighed, i et klart og velordnet Foredrag traadte Taleren op for Berettigelsen af Guds Ords offentlige Forkyndelse ved Lægmænd og henstillede til Foreningen, om den ikke fandt det berettiget at udsende Colporteurer for ogsaa at tale Guds Ord offentlig i Forsamlinger«.

Om den nærmere Begrundelse af denne frimodige Henstilling fra Ordføreren tier Referatet desværre. Om Holm vides, at han har haft nogen Forbindelse med den Lægmandsmisson, som allerede paa det Tidspunkt var i Gang i Vestslesvig ved Lægprædikanten H. P. Nielsen fra Skads og senere, i Aaret 1880, førte til Stiftelsen af "Luthersk Missionsforening for Vestslesvig". Herfra kendte han altsaa Lægmandsforkyndelsen af Selvsyn. Helt umuligt er det maaske heller ikke, at han kan have kendt et lille Skrift "Brudgommen og Bruden. Syv Taler holdte ved gudelige Forsamlinger af Mads Jensen, Kolportør «, udkommet i Haderslev i Aaret 1872, hvori denne Lægpradikant forsøger et Forsvar for sin offentlige Forkyndervirksomhed. Jeg vil gengive det paagældende Afsnit som en samtidig Røst og et Udtryk for, hvordan man dengang saa paa dette Spørgsmaal i Lægmandskredse.

Mads Jensen, der jo havde rejst som Kolportør og Lægrrædikant for Foreningen af 1868, skriver: "Der føres en Kamp mellem Læg og Lærd, om hvem der skal forkynde Jesu Død og Opstandelse, den Lærde vil ikke, at Lægmanden bør tale, og den troende Lægmand vil ikke tie, eftersom det maa og skulde være klart for enhver Troende, at det er et skjændigt Misgreb at maale Kaldelsen med Kundskabens Alen. Var det ikke bedre at have Øje for Her- 
rens Ord og rette sig derefter end at hange saa haardt ved Former og Vedtægter, at Herren maatte sige, om han kom nu og stod midt iblandt os, som for til det jodiske Folk: "I forkaste mig formedelst eders Vedtagter« (Mt. 15, 3). Mon Paulus vel skulde have fejlet, naar han siger: "Menigherlens Tjener hør ikke vare ny i Troen« (1. Tim. 3,6). Kunde det da ikke billigt forlanges, at der blev taget IIensyn til, om den, der skulde vare Leder for Herrens Merighed, selv var Ejer af vor Ilerre og hans Naade, og saa at han bevarede Troens Hemmelighed i en god Samvittighed (1. Tim. 3, 9). IIvor vidt dette skeer, skal jeg ikke afgjøre, men det veed jeg, at de forste, som havde Befaling af Englene til at forkynde Frelserens Fødsel, vare Bethlehems Hyrder (Luc. 2, 18), og da han selv fremstod som den store Lmrer sendt fra Gud, vare de, han sendte ud, maalt med denne Verdens Kundskabs-Alen. kun simple og ulærde Folk, og atter da det store Budskab skulde bringes ud, at Dodens Magt var brudt, "Jesus er opstanden«, vare de første Kvinderne fra (ialilma, der havde fulgt ham, og som nu kom den første Dag i Ugen for at salve ham (Marc. 16, 7). Og Venner, det har vist sig mange Gange siden, at vor Herre har Brug for Mennesker, som vel for Verden synes svage og ulærde, til at forkynde det store Budskab til Liv, Glæde og Fred "Jesus er opstanden«.

Saavidt Mads Jensen. Vi gaar vel ikke fejl, om vi antager, at Degn Holm har sagt noget lignende. Men han fandt ikke Ørenlyd hos Præsterne. Thi Mødereferatet fortsætter: "Med ligesaa megen Varme, med stor Klarhed og moden Besindighed blev dette Referat imødegaaet af Pastor Reuter fra Broager, idet samme paa Grund af Guds Ord og vor Kirkes Bekendelse og al kirkelig Orden ikke kunde ansee Foreningen for berettiget til, ikke for at have Magt og Myndighed til at udsende Colporteurer i den bestemte Hensigt at prædike, offentlig at forkynde Guds Ord, iclet dette var det kirkelige Embedes Gjerning. Dog vilde han paa ingen Maade frakjende Lægmanden Berettigelsen til overhovedet at tale Guds Ord. Thi enhver Huusfader skulde gjøre det i sit Huus, og en Colporteur fik Lejlighed nok hertil, naar han med sine Bøger gik fra Huus til Huus. Her var Arbejde nok; man burde vogte sig for at give sig selv et offentligt 
Prædikeembede. Foreningen var paa ingen Maade kirkeligt berettiget til at udsendr, Colporteurer $i$ den Hensigt offentligt at prædike. Det kunde kun den lovlige kirkelige Øvrighed og den krævede sine Garantier og gav ikke Prædike-Embedet paa Maa og Faa."

Det var klar og tydelig Besked.

Pastor Reuters Grunde imod offentlig Lægmandsforkyndelse er tre, nemlig den hellige Skrift, Kirkens Bekendelsesskrifter og den kirkelige Orden, som faar sit Udtryk i det kirkelige Prædikeembede, til hvilket den kirkelige Øvrighed har Kaldelsesret. Med denne Bevisførelse var i Virkeligheden Traditionen sat op imod Guds Ord og Bogstaven ført i Marken mod Aanden. Og da det første Bevis ikke holder Stik, falder dermed ogsaa de andre.

Det er tydeligt, at Reuters Modreferat var godt forberedt hjemmefra. Højst sandsynligt er det bleven holdt efter Opfordring. Det blev en blank Afvisning fra Præsternes Side. Foreningen kunde ikke gaa med til at udsende Lægprædikanter. Den maatte holde sin fra Begyndelsen fastlagte Kurs og ikke paa nogen Maade gøre Overgreb mod det kirkelige Embede. Saadan opfattede man i hvert Fald Lægmandsforkyndelsen, hvilket jo ikke er saa mærkeligt, naar man saa paa sin egen Præstegerning som et priviligeret Embede.

Efter disse to Indlæg for og imod Lægprædikanten fulgte, som det var at vente, en livlig Forhandling, under hvilken man kom ind paa Forholdene i Urmenigheden i saa Henseende. Droftelsen syntes derefter at skulle munde ud $i$ Vedtagelsen af en Resoldition gaaende ud paa, at Foreningen blandt sine Formaal skulde optage et Arbejde for Oprettelsen af en kirkelig Diakonanstalt, altsaa et Sidestykke til Diakonisseanstalten og med de syv saakaldte Fattigforstandere i Ap. Gern. 6 som Forbillede.

Hvad var det for en Situation, man stod i paa (let nævnte Møde? En Situation, vi, der staar paa Afstand og kender noget til den følgende Udvikling, bedre kan overse, end de kunde det dengang. Det var Lægmanden, der bankede paa Kirkens Dør og krævede sin Ret og sit Ansvar. Kirkens Embedsmænd 
søgte at indfange den tilbudte kristelige Energi og gore den frugtbar i et Diakonarbejde, som skulde underordnes Prædikeemibedet og ikke maatte komme til at konkurrere med dette.

Lykkedes Præsternes Forehavende hin Dag? Nej - Referatet fortsætter: "Imidlertid optoges Discussionen om Lægmands Prædiken atter, og de modsatte Anskuelser optraadte skarpere imod hinanden." Der laa - glædeligvis tør vi sige - Lidenskab bag ved begge Standpunkter. Begge Parter mente at drage Sandhedens Sværd. Hvad nu? Man maatte se at naa til en Flertalsvedtagelse. - Ak, Sandheden er som. Regel i Mindretal! - Et af Wacker stillet Forslag blev forkastet, et andet af Lawaetz ligeledes, det sidste uden engang at faa Tid til at blive rigtig formuleret. Jeg antager, at det har været lægmandsvenligt. Endelig vedtoges et Forslag af Kaftan med et "Ammendement" af Reuter. Det lød saaledes: "Foreningen udsender som hidtil Colporteurer, men overlader det til selve Colporteurerne og de betræifende Sognepræster, om Colporteurerne skulle tale $i$ en Forsamling eller ej. Foreningen søger endvidere at virke hen til Oprettelsen af en kirkelig Diaconanstalt."

Kaftan fik det sidste Ord og bestemte Fremtidskursen, den sognekirkelige Linie kan vi vel sige. Kaftan har aldrig været nogen stor Ven af Lægprædikanten, er heller aldrig kommet i noget nærmere Forstaaelsesforhold til den senere Tonnesenske Indre Mission i Nordslesvig og dens læge Udsendinge.') Han var helt igennem Højkirkemand ${ }^{2}$ ). Aaret efter indtraadte han i Foreningens Bestyrelse, medens Lawaetz, der øjensynligt var lægmandsvenlig, traadte ud. Den vedtagne Resolution tillod i Teorien offentlig Lægmandsforkyndelse, dog uden at Foreningen som saadan vilde tage Ansvaret for den, endsige da selv udsende Lægprædikanter. Sognepræsterne maatte selv tage Initiativet og Ansvaret i Sagen, men

1) Fremhævet af C. Matthiesen i "Kirchen- u. Schulblatt«. i sin Omtale af Kaftans "Eriebnisse und Beobachtungene.

2) Smlgn. hans Bog: "Vier Kapitel von der Landeskirche«, 1903. 
da disse saa godt som alle ikke var stemt for Kolportørers offentlige Prædiken, betød Resolutionen i Praksis en Afvisning af Lægmandskravet om Forkyndervirksomhed. ${ }^{1}$ ) Dermed havde Foreningen som kirkelig Bevægelse betragtet givet sig selv sit Dødsstød. Den var fra nu af at sammenligne med en Dødsskude, selv orn den med meget Besvær har holdt sig oven Vande indtil 1918. Den nylig afdede Pastor Hansen, Dybbøl, var dens sidste Formand.

Wacker nedlagde Formandsposten og "meente ikke mere at kunne forblive i Foreningen." Med hvilke Tanker og Følelser han har sagt Farvel til den Forening, i hvis Tilblivelse han havde saa væsentlig en Andel, er ikke nemt at sige. Helt let er det vistnok ikke blevet for ham. Dog, hvem veed det? Han har vel følt, at han ikke mere var Herre over Elementerne. Lægmandskravet om at faa Del i Forkyndervirksomheden har aabenbart ikke fundet hans Behag, medens han senere hen blev venligere stemt og forsvarede Lægprædikanten som en berettiget Udvej i Nødstilstande, naar enten Sognene blev for uoverkommelige, eller den rene Lære forsvandt fra Prædikestolene. ${ }^{2}$ ) Det Kaftanske Fol'standsdiplomati har sikkert heller ikke behaget hans robust-ærlige Natur. Det skulde være sært, om han ikke allerede dengang har vejret, at de to, Præste- og Degnesønnen, ikke var stobt i samme Ske, som det senere noksom kom for Dagen. De demokratiske Principper, han under en Forenings Forudsætninger maatte boje sig for, har muligvis ogsaa været hans aristokratisk anlagte Natur imod. Paa den anden Side - og det turde maaske nok være det tungeste Lod i Beslutningens Vægtskaal - optog hans nye Forstandergerning ham fuldstændigt. Saa opgav han da Foreningshvervet. Nordslesvig behøvede han jo ikke at

1) Som Undtagelse kan dog foruden Lawaetz ogsaa navnes Pastor Nielsen i Højrup, der tog venligt imod Lægprædikanter, ogsaa fra Kongeriget. Han blev jo ogsa siclen hen den første Formand for den nye lægmandsvenlige Indre Missionsforening af 1886.

$\left.{ }^{2}\right)$ Se hans bemærkelsesværdige Skrift "Die Laienpredigt und der Pietismus in der lutherischen Kirche. Zwei Vorträge nebst einem Nachtrag." 1889. 
opgive, fordi han nedlagde sit Hverv som Formand $i$ dens ev.-luth. Missionsforening. Han saa vel ogsaa, at han som Diakonissesagens Talsmand helst burde staa uafhængig og paa denne Vis bedre kunde knytte de stærke Baand mellem Flensborgs Moderhus og Nordslesvigs Sognemenigheder, som han onskede at knytte og faktisk har knyttet gennem godt en Menneskealder. Han fratraadte sin Forstanderplads i 1910 og døde den 2. 4. 1913. Hvad han iøvrigt har betydet som Husfader for en voksende Diakonissefamilie og som Præstelærer for store Dele ogsaa af Nordslesvigs Præsteskab, som han fra 1893 samlede til et to Dages Konvent ("Luth. Konferenz") paa Anstalten i Flensborg, skal ikke vurderes her. Men det er ikke Smaating.

Næste Aarsmøde i den uden Wacker fortsættende Forening blev bestemt til Afholdelse i Broager, hvorhen Pastor Reuter indbød. Ogsaa denne Indbydelse fra Præsternes Ordfører i Lægmandsspørgsmaalet og dens Modtagelse maatte være med til at fastlægge Foreningens Fremtid. $\mathrm{Nu}$ vidste man, hvorfra Vinden bæste. Kollekten blev kun 369,15 Mk., Halvdelen af den i Løgumkloster Aaret forud.

Formandshvervet blev overtaget af Claussen, der for saa vidt var selvskreven til denne Plads, idet han fra først af var den særligt interesserede i Hedningemissionsopgaven. Efter som Udviklingen havde formet sig, maatte denne nu anses for at være Foreningens egentlige og nærmest liggende Hverv, nemlig Understøttelsen af Missionær Petersen, der paa dette Tidspunkt skulde til at bygge Missionsstation i Tirupati. Dernæst skulde der herhjemme arbejdes for "Diaconien $i$ dens fulde Omfang, i første Linie Diakonisseanstalten i Flensborg, dog vil man ikke træde dem for nær, der vil understøtte Altona." Der har saaledes været Altonaer Diakonisser stationeret i Haderslev indtil 1886. Men til Diakonien hører jo nu ogsaa Arbejdet for Oprettelsen af en Diakonanstalt. Den nye Formand finder det heldigt, at man kom ind i dette Spor. Sagen er foreløbig dunkel for de fleste, men man agter at søge og give Oplysning om den. Det var bebudet, at man paa den sidste Missionsfest i Breklum vilde komme ind paa den, men 
det var desværre ikke sket. I det hele taget kan man vist sige, at Spørgsmaalet dengang endnu ikke var modent til Virkeliggørelse. Den ydre Anledning, der skulde fremtvinge det nye, og Manden, der sad inde med den skabende Evne, savnedes endnu. ${ }^{1}$ )

Af betydelig historisk Interesse er det forøvrigt at erfare, at der samtidig med Missionsfesten i Rise Sogn blev afholdt et Møde i Aarhus angaaende Diakonsagen. Til dette Møde var flere hernede fra indbudte, medens de dog paa Grund af eget Aarsmøde ikke kunde møde frem. ${ }^{2}$ ) Aarhusmødet, der som bekendt førte til Stiftelsen af Stefansforeningen ${ }^{3}$ ) er formodentlig skabt ud af samme Situation som den, der forelaa hernede, Lægmandskravet om Deltagelse i offentlig Prædikevirksomhed og højkirkeligsindede Præsters Afvisning af dette med Anvisning paa den Vej, der mentes at være den rette. Vi veed jo, at der hverken i Nord- eller Sønderjylland blev Tale om Diakonanstalt i den første Menneskealder derefter. Andre Krav pressede mere paa og fik deres Opfyldelse. Lægprædikanten oplevede sin Blomstringstid i vore Egne og gav sin betydelige historiske Indsats i Nordslesvigs kirkelige Liv.

Men det blev altsaa ikke indenfor Nordslesvigs ev.-luth. Missionsforening, at Lægprædikanten fik sit Hjem. Denne Forening fastholdt sin højkirkelige Kurs og gjorde under disse Forudsætninger et trofast Arbejde for Tirupatimissionen, men naaede aldrig at underholde mere end een Missionær paa Missionsmarken. Den kæmpede fra det Tidspunkt en udmattende Kamp mod den snigende Død.

Til Gengæld begynder Breklum ved samme Tid at strække sine Arme ud imod Nordslesvig. Det er $\mathrm{Pa}-$

1) Thade Petersen har velvilligst gjort mig opmarkso mpaa, at den bekendte Pastor Paulsen i Kropp ved Slesvig allerede i 1872 begyndte paa Diakonuddannelse, vel nok med Forbillede i Wicherns "Rauhes Haus" ved Hamborg. Og da Pastor Claussen havde livlig Forbindelse med Kropp, tør vi vel antage en vis bestemmende Indflydelse paa hans Syn herfra.

$\left.{ }^{2}\right)$ »K. S.《 29. 10. 76.

3) Smlgn. Bøn og Bønhørelse. Fra Diakoniens Verden. Udgivet af Diakonhøjskolen i Aarhus, 1930, S. 5. 
stor Nielsen i Højrup, som er særlig ivrig med at give Oplysninger om den nye Missionsvirksomhed $i$ Breklum, der i Lighed med Flensborg beliggende paa Sproggrænsen mellem Dansk og Tysk ogsaa vil erobre Nordslesvig som sit Opland. Der skal dernede byg. ges en Missionsanstalt for »hele Slesvig-Holsten«, saa Provinsen kan faa sin egen Hedningemission. Lederen, den bekendte Pastor Jensen, prædiker i den Anledning i Løgumkloster den 5. 10. 1876 paa Tysk.

Claussen, der efter Wacker tillige definitivt har overtaget Redaktionen af Søndagsbladet, er lidt ilde berørt af Breklums Paatrængenhed og formaner til Trofasthed mod den først betroede Missionsopgave i Tirupati. Glemmer ikke den første Kærlighed, glemmer ikke Tarupati, bliver herefter hans stadigt gentagne Paamindelse. Han er ikke tryg ved Fremtiden, naar Breklum tager hans Missionsvenner fra ham. Han er heller ikke helt tryg ved Breklum, som i hans Øjne har metodistiske Tendenser i Modsætning til en "sund luthersk Retning".

Men skulde Breklum have Fremtiden i Nordslesvig, som den faktisk fik den siden hen under nordslesvigske Mænds Ledelse som Præsterne Bahnsen og Bracker, og skulde Ev.-luth. Missionsforening ledes af højkirkeligt sindede Præster indenfor den tyske Statskirke, er det ikke til at undres over, at den danske Frimenighedsbevægelse vandt stigende Tilslutning mod Nord. Kloppenborg fra Harreby (død 1878) synes ganske stille, uden at det nævnes, at være gledet ud af Bestyrelsen. Kolportør Jensen beretter da ogsaa fra sin fønste Rejse i Foraaret 1876 , at der i Hygom Sogn ikke var saa faa, "som vare udtraadte af Statskirken og vare gaaede over til Grundtvigianismen«. Han fortsætter med følgende Forklaring. "Vor Herre Jesus siger: Hvo der ikke vil fornægte sig selv og tage sit Kors op og følge mig efter, kan ikke være min Discipel. Nu til Dags findes der desværre saare Mange i Christenheden, som nok vil bære Christi Navn, ogsaa nok for en Deel ville vise sig som Christi Tjenere, men ikke som Christi Efterfølgere.... Vi ville nok opføre os som skikkelige Folk og som saadanne, der ved egen Dyd og gode Gjerninger (i det mindste for en Deel) kunne erhverve sig Himlen; 
men at antage det, som er os givet og forhvervet til Gjenoprettelsen af vor Salighed, som Guds Søn har tilkjæmpet os ved sin Lidelse og Død, det ville vi ikke. $\left.\kappa^{1}\right)$

Ja, saadan saa man dengang (og indtil 1920) fra tysk Side paa den danske Frimenigheds Opstaaen. (I Dag vil jeg tro, at man i egen berettiget Interesse ser noget anderledes paa Sagen.) Dens dybe Grunde til kristeligt og folkeligt selv at tage fat, havde man ikke Øje for. Og saa beskyldte man den for religiøs Overfladiskhed. Dens Ordførere blev kristusgrebne danske Lægmænd.

Ev.-luth. Misisonsforening afviste, som vi saa, Lægprædikanten. Da der derimod et Aarti senere atter opstod en Indre-Missions-Bevægelse i vort lille Hjemland, nemlig den Tonnesenske i 1886 , blev den paabegyndt udtrykkeligt som Lægmandsmission. Man antog den i Nordslesvig hjemmehørende Lægprædikant Lars Birk, der i Forvejen havde staaet 15 Aar i Indre Missions Tjeneste i Kongeriget, som første Udsending i Nordslesvig. Han efterfulgtes af mange flere. Nu vidste man i Modsætning til Præsterne paa Mødet $i$ Rødekro en halv Snes Aar tidligere at føre baade den hellige Skrift og Luther i Marken for offentlig Lægmandsprædiken.')

1) "K. S.« $28.1,77$.

2) Smlgn. Tonnesen: "Hvad vi vilde 1886" i "Sæedekornets Jubilæumsudgave« 1911, S. 8-13. 